Al-Bayyinah: Journal of Islamic Law- ISSN: 1979-7486 (p);

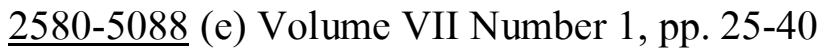

\title{
PEMUTUSAN PEMINANGAN SECARA SEPIHAK MENURUT PERSPEKTIF HUKUM ISLAM
}

\section{Herinawati}

(Dosen Fakultas Hukum Universitas Malikussaleh)

\section{Abstract}

This study addresses the issue of termination peminangan unilaterally according to the perspective of Islam, mainly to do with the status of money shopping (dui menre) in the perspective of Islamic law. In addition, it also aimed to find out the Customs termination peminangan sanctions unilaterally according to the perspective of Islamic law. Dui Menre included in the structure of indigenous norms that have been rooted in the culture of Bugis and has become a requirement for the continuation of the Bugis culture within the Covenant of marriage. The issue of Islamic law menre Dui entered in terms of the tahsiniyyah even though according to the custom of Dui menre belongs to the category in terms of wedding customs. So the customs in this regard is under the law the legitimate and a requirement that could cancel the halal in the one is not accepted. Therefore, the law menre Dui according to Islamic law is mubah (permissible) because of its position as a grant.

Kata Kunci: pemutusan peminangan, dui menre, mahar, hukum Islam 


\section{A. Latar Belakang}

Manusia pada dasarnya adalah makhluk sosial yang memiliki naluri untuk hidup dengan orang lain. Naluri manusia untuk selalu hidup dengan orang lain disebut gregariousness sehingga manusia juga disebut sosial animal (hewan sosial). ${ }^{\prime}$

Sebagai makhluk sosial, manusia akan mencari hakikat dirinya. Adanya tindakan-tindakan manusia merupakan perwujudan dari ide-ide serta pikiran-pikiran guna memperoleh sesuatu sebagai kebutuhan, demikian pula terhadap hubungan timbal balik antara sesamanya. Salah satu hubungan sosial antara manusia yang akan menjadi pokok pembahasan dalam tulisan ini adalah hubungan manusia lain, hubungan mana yang kelak menjadi tali pengikat untuk suatu hubungan darah kekerabatan yaitu perkawinan.

Perkawinan merupakan salah satu cara untuk melegalisasikan suatu status sosial dan menciptakan hak dan kewajiban yang diakui secara hukum.Dalam Undang-undang Perkawinan Pasal 1 UU No. 1 Tahun 1974 disebutkan bahwa:

"Perkawinan ialah ikatan lahir batin antara seorang pria dengan seorang wanita sebagai suami istri dengan tujuan membentuk keluarga (rumah tangga) yang bahagia dan kekal berdasarkan kepada Ketuhanan yang Maha Esa.".2

Perkawinan Bugis adalah salah satu perkawinan di Indonesia yang paling kompleks dan melibatkan banyak emosi. Bagaimana tidak, mulai dari ritual lamaran hingga selesai resepsi pernikahan akan melibatkan seluruh keluarga yang berkaitan dengan kedua pasangan calon mempelai. Ditambah lagi dengan biaya mahar dan Dui menre atau biaya akomodasi pernikahan yang selangit.

Tradisi uang belanja (Dui menre) pada masyarakat Bugis Bone ini dipercaya mampu menaikkan status sosial seseorang yang tergantung dari berapa jumlah uang belanja (Dui menre) yang akan diberikan. Seperti pada masyarakat golongan menengah ke bawah yang dengan cepat bisa

${ }^{1}$ Soerjono Soekanto, Kamus Hukum Adat, (Cet. II; Bandung: Alumni, 1982), h. 212.

${ }^{2}$ Undang-undang RI No. 1 Tahun 1974 Tentang Perkawinan dan Kompilasi Hukum Islam, (Cet. I; Bandung: Citra Umbara, 2007), h. 2. 
mendapatkan status sosial tinggi hanya akibat tingginya uang belanja (dui menre) yang diajukan oleh mempelai laki-laki. Di samping dari status sosial, indikator besar kecilnya uang belanja (dui menre) bisa dilihat dari kemewahan pesta pernikahan. Hal ini kemudian menjadi masalah dimana hampir semua masyarakat ingin menikahkan anaknya dengan jumlah uang belanja (dui menre) yang tinggi untuk kepentingan derajat sosial di tengah masyarakat. ${ }^{3}$

Dalam tulisan ini, penulis akan membahas mengenai tradisi perkawinan di kalangan masyarakat Bugis Bone yang mengenal tradisi uang belanja (dui menre) yang pembahasannya lebih kepada Perspektif Hukum Islam.

\section{B. Rumusan Masalah}

Berdasarkan uraian latar belakang di atas, maka masalah pokok yang penulis ajukan dalam penelitian ini adalah "Bagaimana perspektif hukum Islam tentang pemutusan peminangan secara sepihak karena ketidaksesuaian uang belanja? Dengan sub masalah sebagai berikut:

1. Bagaimana status uang belanja (dui menre) dalam perspektif Hukum Islam?

2. Bagaimana sanksi adat pemutusan peminangan secara sepihak karena ketidak kesesuaian uang belanja menurut perspektif hukum Islam?

\section{Tujuan dan Kegunaan Penelitian}

1. Tujuan Penelitian Adapun yang menjadi tujuan dalam penelitian ini sebagai berikut:

a. Untuk mengetahui bagaimana status uang belanja (dui menre) dalam perspektif Hukum Islam.

b. Untuk mengetahui sanksi adat kedudukan pemutusan peminangan secara sepihak karena ketidaksesuaian uang belanja menurut perspektif hukum Islam.

${ }^{3}$ Hamid Abdullah, Manusia Bugis Makassar: Suatu Tinjauan Historis Terhadap Pola Tingkah Laku Dan Pandangan Hidup Manusia Bugis. (Jakarta: Inti Idayu Press, 1985), h. 97. 
2. Kegunaan Penelitian

Adapun kegunaan penelitian ini sebagai berikut:

a. Dari segi kegunaan teoretis/ilmiah. Studi ini dapat dijadikan sebagai salah satu bahan dasar pemikiran dalam upaya menemukan suatu teori pengetahuan.

b. Kegunaan praktis; hasil penelitian dapat dijadikan dasar pengembangan penelitian lebih lanjut bagi penelitian berikutnya dan sekaligus menambah kepustakaan Hukum Islam.

\section{Metodologi Penelitian}

Penelitian ini adalah penelitian pustaka (Library Research) yang bersifat deskriptif-kualitatif. Pendekatan yang digunakan, yakni pendekatan yuridis dan sosiologis. Variabel yang dianut dalam penelitian ini adalah uang belanja menurut perspektif hukum Islam. Penerapan uang belanja sebagai variabel pertama dan pemutusan peminangan secara sepihak karena ketidaksesuaian uang belanja menurut perspektif hukum Islam sebagai variabel kedua. Sementara, sumber datanya adalah sumber data primer dan data sekunder.

Teknik pengumpulan data dilakukan dengan menggunakan teknik penelitian kepustakaan (Library Research) yaitu dengan cara membaca literatur-literatur yang dijadikan sebagai pedoman atau sumber data dalam pembuatan penelitian. Data yang dihimpun kemudian dikumpulkan lalu diklasifikasikan berdasarkan variabel-variabelnya, lalu dilakukan pemilihan data, berdasarkan primer sekunder dan relevan. Sedangkan, analisis data dalam penelitian ini terdiri atas tiga jenis kegiatan, meliputi (1) penyajian data yang sudah terkumpul, (2) analisis data dalam bentuk reduksi dan (3) penarikan simpulan.

\section{E. Hasil Pembahasan}

1. Sejarah dan Pandangan Hukum Islam Tentang Uang Belanja (Dui Menre) dalam Perkawinan

Ketika orang Bugis akan mengadakan pesta perkawinan, hal yang paling penting yang akan dibicarakan adalah mahar dan uang belanja (dui menre). Sejak 30 tahun terakhir Dui menre dalam tradisi orang bugis telah menjadi 
momok yang menakutkan bagi para pemuda yang semakin cenderung meningkat dari waktu ke waktu. Pihak keluarga perempuan tidak tanggung-tanggung mematok jumlah dui menre yang terbilang fantastis dan cukup tinggi yaitu sekitaran dua puluh juta, tiga puluh juta, lima puluh juta bahkan sampai ratusan juta.

Mahar dalam pernikahan Bugis terdiri atas dua jenis uang serahan, yakni serahan "mahar" (sompa [Bugis]) dan "uang belanja" (dui menre [Bugis]), dan besaran masing-masing uang serahan tersebut memiliki makna yang berbeda. ${ }^{5}$ Mahar atau sompa dinyatakan dalam sejumlah nilai perlambang tukar tertentu yang tidak berlaku lagi secara nominal dan tidak mempunyai nilai yang dapat dibanding dengan nilai uang yang berlaku sekarang. Besaran ini sudah ditentukan jumlahnya secara adat, berdasarkan derajat tertentu, sesuai garis keturunan si calon mempelai wanita. ${ }^{6}$

Secara sederhana, uang naik dapat diartikan sebagai uang belanja, yakni sejumlah uang yang diberikan oleh pihak mempelai laki-laki ke pihak mempelai perempuan. Uang naik ini ditujukan untuk belanja kebutuhan pesta pernikahan. Besar kecilnya uang naik, ditentukan oleh pihak perempuan. Selain itu, status sosial juga seringkali jadi penentu besar kecilnya uang naik ini. ${ }^{7}$

Christian Pelras menjelaskan bahwa dalam tradisi Bugis, uang naik disebut juga dui' menre'. Dui' menre' ini merupakan salah satu bagian dari mas kawin, selain sompa yang secara harfiah berarti 'persembahan'. Sompa ini sendiri berbeda dengan mahar dalam konsepsi hukum Islam yang sekarang disimbolkan dengan sejumlah uang rella', yakni rial (mata uang Portugis yang sebelumnya berlaku,

${ }^{4}$ Christian Pelras, Manusia Bugis (Jakarta-Paris EFEO Nalar Bekerjasama Dengan Forum, 2005, h. 10.

${ }^{5}$ Christian Pelras, Manusia Bugis, h. 11.

${ }^{6}$ Christian Pelras, Manusia Bugis, h. 11.

${ }^{7}$ Didit Putra Erlangga Rahardjo “Makna Adat Permikahan Bugis Bergeser". diakses pada tanggal 16 Agustus 2017. 
antara lain, di Malaka). Rella' ditetapkan sesuai status perempuan dan akan menjadi hak miliknya. ${ }^{8}$

Uang belanja (dui menre) ini adalah sejumlah uang yang diberikan oleh calon mempelai pria kepada calon mempelai wanita yang merupakan bentuk penghargaan dan realitas penghormatan terhadap norma dan strata sosial. Dui menre' ini belum terhitung sebagai mahar penikahan, melainkan sebagai uang adat namun terbilang wajib dengan jumlah yang disepakati oleh kedua belah pihak atau keluarga.

Christian Pelras menjelaskan bahwa dalam sejarah tradisi Dui Menre dalam budaya Bugis, dilatar belakangi oleh 3 faktor utama yakni: pengaruh budaya kerajaan, pengaruh status sosial, pengaruh kolonialisme penjajahan Belanja. ${ }^{10}$

Pada suku Bugis (masyarakat Bugis) menganut tiga tingkatan sosial, ${ }^{11}$ yaitu:

a. Ana' Arung, yaitu lapisan teratas, yang terdiri atas dua tingkatan sosial, yaitu Ana' Jemma (anak bangsawan yang lahir pada saat ayahnya memerintah/menjadi raja) dan Ana' Mattola (anak bangsawan dari raja yang lahir sebelum atau sesudah ayahnya memerintah).

b. To Maradeka, terdiri atas tiga tingkatan sosial, yaitu Ana' Mattola Matase (anak yang lahir dari hasil perkawinan ayah dan ibu dari tingkatan sosial yang sama), Ana' Mattola Malolo (anak yang lahir dari perkawinan ayah yang lebih tinggi darah kebangsawanannya dari pada ibunya), dan Ana' Cera'(anak yang lahir dari perkawinan antara seorang bangsawan dengan orang biasa). ${ }^{13}$

${ }^{8}$ Didit Putra Erlangga Rahardjo “ Makna Adat Pernikahan Bugis Bergeser". diakses pada tanggal 16 Agustus 2014.

${ }^{9}$ Muhammad Nur Rasuly,. Monografi Kebudayaan Bugis Di Sulawesi Selatan (Pemerintah Daerah Tingkat I Sulawesi Selatan, 1984), h. 22.

${ }^{10}$ Christian Pelras, Manusia Bugis h. 48.

11 Mattualada, Latoa (Yogyakarta: Gadjah Mada University Press, 1985), h. 120 .

${ }^{12}$ Mattualada, Latoa, h. 143.

${ }^{13}$ Mattualada, Latoa, h. 144. 
c. Ata, yaitu orang yang tidak diperbudak oleh orang lain, yang terdiri atas dua lapisan, yaitu To Baji (orang baik) dan To Samara (orang biasa).

Pelapisan sosial yang terdapat dalam struktur sosial masyarakat Bugis, yang cenderung disebut tertutup adalah masalah yang menyangkut sistem perkawinan antara seorang pria dari lapisan bawah dengan seorang perempuan lapisan atas. Lahirnya sistem ini adalah berkaitan erat dengan posisi wanita dalam kehidupan keluarga yang menjadi lambang kehormatan keluarga.

Menggarisbawahi bahwa hukum Dui'menre' menurut hukum Islam adalah mubah (boleh) karena kedudukannya adalah sebagai hibah. Pemberian dui menre' dalam pernikahan adat Bugis merupakan persyaratan (kewajiban) adat bukan berdasarkan syar'i. Jadi menurut hukum Islam orang boleh memberikan atau tidak memberikan dui menre'.

\section{b. Peminangan dan Pandangan Hukum Islam Tentang Mahar dalam Perkawinan}

Menurut etimologi meminang atau melamar adalah meminta wanita untuk dijadikan istri. Sedangkan menurut terminologi peminangan adalah kegiatan upaya ke arah terjadinya hubungan perjodohan antara seorang pria dan seorang wanita. Atau, seorang pria meminta kepada seorang perempuan untuk menjadi istrinya. Dengan cara-cara yang umum berlaku di tengah-tengah masyarakat. ${ }^{14}$

Adapun dasar disyari'atkannya peminangan adalah berlandaskan kepada:

1. Firman Allah dalam surat al-Baqarah (2) ayat 235:

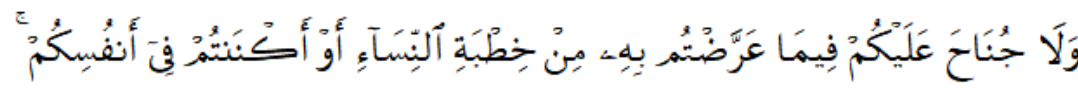

Terjemahnya:

Tidak ada halangannya bagimu menggunakan kata sindiran dalam meminang perempuan atau kamu

14 Abd. Rahman Ghazaly, Fiqh Munakahat, (Jakarta: Prenada Media, 2003), h. 73-74. 
menyembunyikan (keinginan mengawini mereka) dalam hatimu.(QS. Al Baqarah : 235) ${ }^{15}$

2. Hadits Nabi yang diriwayatkan oleh Imam Ahmad dan Abu Daud dengan sanad yang dipercaya yaitu:

و عن جابر رضي الله عنه قال: قال رسول صع اذا خطب احدكم المر أة

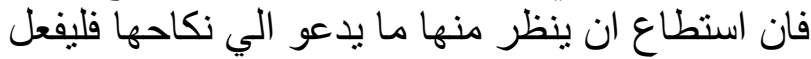

Artinya:

Bila salah seorang diantaramu meminang seorang perempuan, bila ia mampu melihatnya yang mendorongnya untuk menikahinya, maka lakukanlah. ${ }^{16}$

3. Hadits Nabi dari al-Musghirah bin Syu'bah yang dikeluarkan oleh al-Turmudzi dan al-Nasaiy yang berbunyi:

النه قال له وقد خطب امر أة انظر اليها فانها احرى ان يؤدم بينكما Artinya:

Bahwa Nabi berkata kepada seseorang yang telah meminang seorang perempuan: " melihatlah kepadanya, karena yang demikian akan lebih menguatkan ikatan perkawinan. ${ }^{17}$

4. Hadits dari Musa bin Abdullah menurut riwayat Ahmad yaitu:

قال رسول الله ص ع اذا خطب احدكم امر أة فلاجناح عليه ان بنظر

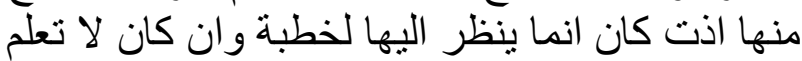

Artinya:

Berkata Rasul Allah $S A W$, bila salah seorang diantaramu meminang seorang perempuan tidak ada halangannya melihat kepadanya bila melihat itu adalah untuk kepentingan peminangan, meskipun perempuan itu tidak mengetahuinya. ${ }^{18}$

${ }^{15}$ Amir Syarifuddin, Hukum Perkawinan Islam Di Indonesia, (Jakarta: Prenada Media, 2006), h. 52.

${ }^{16}$ Ibnu Hajar Al-Asqalany, Bulughul Maraam (Surabaya: AlHidayah,tt), h. 200.

${ }^{17}$ Ibnu Hajar Al-Asqalany, Bulughul Maraam, h. 200.

${ }^{18}$ Muhammad bin Ali al-Syaukany, Nayl Al-Awthar, (Beirut: Dar AlJail Islamiyah), h. 239. 
Syarat perempuan yang sah atau boleh dinikahi secara syara' dan tidak ada halangan lain yang mencegah untuk dipinang serta ketentuan lain yaitu: ${ }^{19}$

a. Perempuan yang sedang berada dalam ikatan perkawinan meskipun dalam kenyataannya telah lama ditinggalkan oleh suaminya.

b. Perempuan yang ditinggal mati oleh suaminya, baik ia telah digauli oleh suaminya atau belum.

c. Perempuan yang telah bercerai dari suaminya dengan talak raj'I dan sedang berada dalam masa iddah raj'i.

d. Perempuan yang telah bercerai dengan suaminya dengan talak bain dan sedang menjalani masa iddah.

Adapun cara menyampaikan ucapan peminangan ada dalam dua cara:

a. Menggunakan ucapan yang jelas dan terus terang dalam arti tidak mungkin dipahami dari ucapan itu kecuali untuk peminangan.

b. Menggunakan ucapan yang tidak jelas dan tidak terus terang atau dengan istilah kinayah. yan $g$ berart $i$ ucapan itu dapat mengandung arti bukan untuk pinangan.

Secara istilah mahar diartikan sebagai "harta yang menjadi hak istri dari suaminya dengan adanya akad atau dukhul". ${ }^{20}$ Mahar ini pada hakikatnya dinilai dengan nilai uang, sebab mahar adalah harta, bukan sekedar simbol belaka. Para ulama' sepakat bahwa mahar wajib diberikan oleh suami kepada istrinya, baik kontan ataupun dengan cara tempo. Pemberian mahar dalam syari'at islam dimaksudkan untuk mengangkat harkat dan derajat kaum perempuan yang sejak zaman jahiliyah telah diinjak-injak harga dirinya. Dengan adanya mahar, status perempuan tidak dianggap sebagai barang yang diperjual belikan. Ulama' fiqh sepakat bahwa tidak ada batasan minimal dan maksimal jumlah mahar yang harus diberikan. Jumlahnya terserah pada kemampuan mempelai laki-

${ }^{19}$ Dikutip dalam buku Soerojo Wigjodipoero, Pengantar dan Asasasas Hukum Perkawinan, (Cet. XII; Jakarta: CV. Haji Masagung, 1994), h. 88.

${ }^{20}$ Amiiur Nurudin, Hukum Perdata Islam di Indonesia (Jakarta:Prenada Media, 2004), h.54. 
laki asal dianggap layak. Tidak ada ketentuan dalam agama yang menunjukkan batasan maksimal yang tidak boleh melebihi hal itu. ${ }^{21}$

Di dalam KHI, mahar diatur di dalam pasal 30 sampai pasal 38 didalam pasal 30 dinyatakan:

Calon mempelai pria, wajib membayar mahar kepada calon mempelai perempuan yang jumlah, bentuk dan jenisnya disepakati oleh kedua belah pihak.

Pasal yang juga sangat penting diperhatikan adalah terdapat di dalam pasal 31 yang berbunyi:

Penentuan mahar berdasarkan atas asas kesederhanaan dan kemudahan yang dianjurkan oleh agama Islam. ${ }^{22}$

Dengan demikian kendatipun mahar itu wajib, namun dalam penentuannya tetaplah harus mempertimbangkan asas kesederhanaan dan kemudahan.

\section{c. Kedudukan Uang Belanja dan Pemutusan Peminangan}

Secara Sepihak Karena Ketidaksesuain Uang Belanja

Menurut Perspektif Hukum Islam

Perkawinan dalam hukum Islam akan mengakibatkan adanya hak dan kewajiban antara para pihak terkait, yaitu pasangan suami istri. Adapun salah satu kewajiban suami yang merupakan hak istri adalah pemberian mahar atau mas kawin dari calon suami kepada calon istrinya. Agama tidak menetapkan jumlah minimum atau maksimum, tergantung pada perbedaan tingkat kemampuan manusia dalam memberinya. Oleh karena itu diserahkan kepada pihak yang bersangkutan atas dasar dengan kerelaan hati. Pemberian itu adalah maskawin yang besar kecilnya ditetapkan atas persetujuan kedua pihak, karena pemberian itu harus dilakukan secara ikhlas.

Pada perkawinan masyarakat Bugis terdapat dua unsur yang tidak dapat dipisahkan dalam proses perkawinan, yaitu pihak laki-laki tidak hanya memberikan mahar, akan tetapi menurut ketentuan adat juga harus memberi Dui' menre' (uang

21 Beni Ahmad Saebani, Fiqh Munakahat (Bandung: CV. Pustaka Setia, 2001), h. 66 .

22 Budi Durachman, Kompilasi Hukum Islam (Bandung:Fokus Media, 2005), h. 14. 
hantaran). Dui' menre' (uang hantaran) dalam pernikahan adat Bugis adalah penyerahan harta terdiri atas uang atau harta yang berupa passio (cincin pengikat), Dui' balanca (uang pesta), Sompa(mas kawin) yang besarnya diukur sesuai dengan stratifikasi sosial dalam masyarakat.

Pada pemikiran hukum Islam (ilmu fiqh) para ahli hukum Islam banyak yang menerima berbagai macam praktek adat untuk dimasukkan ke dalam teori hukum Islam selama tidak bertentangan dengan prinsip-prinsip syari'at. Abu Hanifah, Imam asy-Syafi'i dan Ahmad bin Hambal, misalnya menggunakan Adat dalam istinbat al-Ahkam dengan syarat tidak menyalahi dalil-dalil serta tidak menghalalkan yang dilarang oleh syari'at. Adat digunakan untuk memelihara kemaslahatan. Mereka melihat prinsip-prinsip adat sebagai salah satu sumber hukum Islam sekunder, dalam pengertian diaplikasikannya prinsip- prinsip adat tersebut hanya ketika sumber primer (al-Qur'an dan Hadis) tidak memberi jawaban terhadap permasalahan yang muncul.

Dui' menre' termasuk dalam struktur dari norma adat yang disebut (ade', assiamaturaseng) yang telah mengakar jauh sebelum Islam datang, Dui' menre' adalah syarat bagi berlangsungnya akad nikah. Selanjutnya melihat definisi Dui' menre' dalam pernikahan adat Bugis adalah uang pesta dalam pernikahan dan jumlahnya tidak mengikat: persoalan $d u i$ menre' dalam hukum Islam masuk dalam hal yang tahsiniyyah walaupun menurut adat dui menre'masuk dalam katagori syarat dalam pernikahan adat. Oleh karena itu, hukum Dui menre menurut hukum Islam adalah mubah (boleh) karena kedudukannya sebagai hibah.

Hukum perkawinan Islam bertujuan untuk mewujudkan sebuah keluarga yang sakinah, mawaddah wa rahmah sebagaimana dinyatakan dalam al-Quran. Oleh karenanya, pendahuluan perkawinan khususnya khitbah atau peminangan merupakan yang dipandangan signifikan menurut Islam. Hal tersebut terlihat dengan adanya beberapa hadis yang menjelaskan tentang khitbah.

Adanya peminangan berarti telah terjadi kesepakatan untuk melakukan perkawinan antara kedua belah pihak pada waktu yang telah ditentukan. Kesepakatan dalam perspektif 
Islam identik dengan perjanjian artinya jika salah satu membatalkan tanpa alasan yang dibenarkan oleh syara' maka pihak yang membatalkan tersebut telah masuk dalam lembah kemunafikan karena ingkar janji sebagaimana sabda Nabi $\mathrm{SAW}^{23}$

$$
\text { أبية المعنافق ثندث إذا و عد خلف و إذا حذت كذب و إذا أتعن خان' }
$$

Tradisi pembayaran sanksi atau denda bagi pihak yang membatalkan peminangan tanpa alasan yang bisa dipertanggungjawabkan dimaksudkan sebagai variabel yang menutup kerugian pada salah satu pihak. Meskipun sebenarnya kerugian yang dialami oleh pihak yang dikhianati tidak saja berupa kerugian material tetapi juga kerugian moral (rasa malu yang mendalam bahkan lebih parah lagi yakni cacat dalam pengertian tidak cepat laku dalam hal menikah). Islam tidak menginginkan hal tersebut terjadi, maka tindakan preventif (pencegahan) dengan menetapkan adanya sanksi atau denda bagi pihak yang memutuskan peminangan lebih diutamakan daripada harus memulihkan atau mengembalikan citra atau nama baik yang tercoreng akibat kekecewaan yang tidak ringan ataupun kerugian lainnya. Berdasarkan pandangan adat di daerah sebagaimana dimaksud, sering terjadi peminangan yang orientasinya menyimpang dari norma-norma kebaikan dan budaya luhur. Misalnya saja ada peminangan yang bertujuan untuk mempermalukan salah satu pihak dengan membatalkannya ketika persiapan perkawinan telah mencapai klimaks. Maka berdasarkan dalil sad az-zari'ah dan maslahah mursalah tradisi di daerah kasus tidak dapat disalahkan begitu saja dalam hal penetapan sanksi bagi pihak yang memutuskan peminangan dengan alasan sepihak. Permasalahan tersebut sejalan dengan kaidah. ${ }^{24}$

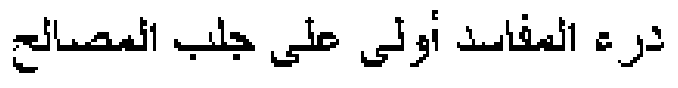

${ }^{23}$ Abi Isa Muhammad bin Isa bin Saurah, Sunan al-Tirmizi, Edisi Kamal Yusuf al-Hut (Beirut: Dar al-Fikr, t.t.), h. 34.

${ }^{24}$ Seperti dikutip dalam buku Mahmud Yunus, Hukum Perkawinan dalam Islam, (Jakarta: al-Hidayah, 1956), h. 36. 
Kebutuhan umat Islam kepada ijtihad merupakan kebutuhan abadi selama masih ada kejadian baru... ${ }^{25}$ atau selama masih ada masalah yang belum tersentuh oleh al-Quran maupun Hadis, baik secara tekstual maupun konstektual. Lebih jauh Abdul Halim menjelaskan bahwa ijtihad kontemporer "mengandung pengertian mencurahkan segala kemampuan untuk menentukan hukum masalah-masalah baru dan problem problem modern berdasarkan nas-nas hukum yang pokok (umum) dan kaidah-kaidah yang bersifat umum. ${ }^{26}$

Ijtihad kontemporer menurut al-Qardawi dapat dilakukan dengan cara ijtihad intiqa'i dan ijtihad insya'i atau gabungan antara keduanya. Ijtihad intiqa'i ialah ijtihad yang dilakukan dengan cara menyeleksi pendapat ulama terdahulu yang dipandang lebih cocok dan lebih kuat. Ijtihad insya'i ialah dengan mengambil konklusi hukum baru dalam suatu permasalahan di mana permasalahan tersebut belum pernah dikemukakan oleh para ulama terdahulu, baik masalah itu baru atau lama. Sedangkan, gabungan antara ijtihad intiqa'i dan ijtihad insya'i adalah menyeleksi pendapat-pendapat ulama terdahulu yang dipandang cocok dan lebih kuat kemudian ditambahkan dalam pendapat-pendapat tersebut unsur-unsur ijtihad baru. $^{27}$

Dan menurut Abd. Al-Wahbab al-Khallaf istislah adalah:

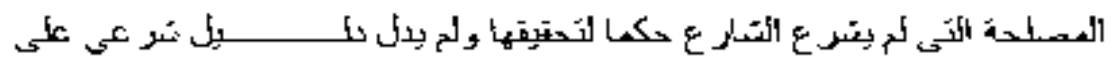

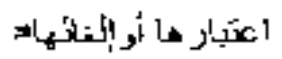

Dari pengertian di atas dapat disimpulkan bahwa istislah atau maslahah mursalah adalah menetapkan hukum suatu masalah yang tidak disebut ketentuannya dalam al-Quran dan as-Sunnah. Penetapan semata-mata dimaksudkan dalam

\footnotetext{
${ }^{25}$ Riyanto, Neo Usul Fiqh: Menuju Ijtihad Konstektual (Yogyakarta: Fakultas Syariah Press dan FSHI, 2004), h. 281.

${ }^{26}$ Yusuf al-Qardhawi, Ijtihad dalam Syariat Islam (Yogyakarta: IAIN Sunan Kalijaga, 1996), h. 201.

${ }^{27}$ Yusuf al-Qardhawi, Ijtihad dalam Syariat Islam, h. 201.
} 
rangka mencari kemaslahatan dan menolak kerusakan dalam kehidupan manusia.

Dengan demikian, kedudukan pemutusan peminangan secara sepihak karena ketidaksesuaian uang belanja menurut perspektif hukum Islam adalah sebagai berikut:

1. Diperbolehkan jika memang 'illat dari pembatalan tersebut sesuai dengan alasan yang bisa dibenarkan oleh syariat Islam. Hal ini sesuai dengan dalil sad az'zari'ah.Sanksi pembatalan peminangan berfungsi untuk menyumbat atau menutup masalah yang sangat krusial dan rawan konflik ini sehinga fenomena serupa tidak terulang, kalaupun tetap terjadi pembatalan, maka sanksi pembatalan peminangan ini dapat relatif meredam dampak pembatalan agar tidak berkepanjangan dengan adanya prosedur yang jelas yaitu pemberlakuan sanksi.

2. Tidak diperbolehkan jika alasan pembatalan peminangan justru berseberangan dengan prinsip maqashid syari.

3. Tidak diperbolehkan jika kedua pihak telah sepakat untuk membatalkan peminangan mereka sendiri.

Bagi masyarakat Bugis, suatu perkawinan adat yang meriah dan megah merupakan suatu kebanggaan bagi keluarga atau kerabat yang bersangkutan. Dan bersangkut pula dengan masalah status sosial dalam kehidupan masyarakat. Sebab itu, sering dijumpai suatu keluarga telah mengerahkan segenap kemampuannya dalam penyelenggaan suatu perkawinan dengan kepalang tanggung jumlah biaya atau dana yang telah dikeluarkannya, terutama pada kelompok lapisan atas yang merasa suatu perkawinan adalah juga menyangkut suatu martabat sosial yang harus diperhatikan dan dinilai oleh masyarakat.

\section{F. Penutup}

Berdasarkan uraian di atas, ditetapkan beberapa simpulan pada penelitian ini sebagai berikut:

1. Dui menre dalam pernikahan adat Bugis adalah uang pesta dalam pernikahan dan jumlahnya tidak mengikat: Dui menre dalam hukum Islam masuk dalam hal yang tahsiniyyah 
walaupun menurut adat Dui menre masuk dalam katagori syarat dalam pernikahan adat. Jadi adat dalam hal ini berada di bawah hukum syar'i dan sebuah syarat yang bisa membatalkan yang halal dalam syar'i tidak diterima. Oleh karena itu, hukum Dui menre menurut hukum Islam adalah mubah (boleh) karena kedudukannya sebagai hibah.

2. Kedudukan pemutusan peminangan secara sepihak karena ketidaksesuian uang belanja menurut perspektif hukum Islam adalah sebagai berikut:

a. Diperbolehkan jika memang 'illat dari pembatalan tersebut sesuai dengan alasan yang bisa dibenarkan oleh syariat Islam. Hal ini sesuai dengan dalil sad az'zari'ah. Sanksi pembatalan peminangan berfungsi untuk menyumbat atau menutup masalah yang sangat krusial dan rawan konflik ini sehinga fenomena serupa tidak terulang, kalaupun tetap terjadi pembatalan, maka sanksi pembatalan peminangan ini dapat relatif meredam dampak pembatalan agar tidak berkepanjangan dengan adanya prosedur yang jelas yaitu pemberlakuan sanksi.

b. Tidak diperbolehkan jika alasan pembatalan peminangan justru berseberangan dengan prinsip maqashid syari.

c. Tidak diperbolehkan jika kedua pihak telah sepakat untuk membatalkan peminangan mereka sendiri. Sehingga masyarakat sekitar dalam pengertian pihak-pihak yang terlibat dalam masalah ini tidak dapat menekan atau memaksa kedua belah pihak yang telah sepakat membatalkan peminangan tersebut untuk tetap membayar sanksi atau denda yang telah disepakati.

\section{G. Daftar Pustaka}

Abdullah, Hamid. Manusia Bugis Makassar: Suatu Tinjauan Historis Terhadap Pola Tingkah Laku Dan Pandangan Hidup Manusia Bugis. Jakarta: Inti Idayu Press, 1985. al-Asqalany, Ibnu Hajar. Bulughul Maraam. Surabaya: AlHidayah,tt.

Durachman, Budi. Kompilasi Hukum Islam. Bandung:Fokus Media, 2005.

Ghazaly, Abd. Rahman. Fiqh Munakahat. Jakarta: Prenada Media, 2003. 
Mattualada. Latoa. Yogyakarta: Gadjah Mada University Press, 1985.

Nurudin, Amiiur. Hukum Perdata Islam di Indonesia. Jakarta:Prenada Media, 2004.

Pelras, Christian. Manusia Bugis. Jakarta-Paris EFEO Nalar Bekerjasama Dengan Forum, 2005.

Rahardjo, Didit Putra Erlangga. "Makna Adat Pernikahan Bugis Bergeser". diakses pada tanggal 16 Agustus 2014.

Rasuly, Muhammad Nur. Monografi Kebudayaan Bugis Di Sulawesi Selatan Pemerintah Daerah Tingkat I Sulawesi Selatan, 1984.

Riyanto. Neo Usul Fiqh: Menuju Ijtihad Konstektual. Yogyakarta: Fakultas Syariah Press dan FSHI, 2004.

Saebani, Beni Ahmad. Fiqh Munakahat. Bandung: CV. Pustaka Setia, 2001.

Saurah, Abi Isa Muhammad bin Isa. Sunan al-Tirmizi. Edisi Kamal Yusuf al-Hut. Beirut: Dar al-Fikr, t.t.

Soekanto, Soerjono. Kamus Hukum Adat. Cet. II; Bandung: Alumni, 1982.

Syarifuddin, Amir. Hukum Perkawinan Islam Di Indonesia. Jakarta: Prenada Media, 2006.

al-Syaukany, Muhammad bin Ali. Nayl Al-Awthar. Beirut: Dar Al-Jail Islamiyah.

Wigjodipoero, Soerojo. Pengantar dan Asas-asas Hukum Perkawinan. Cet. XII; Jakarta: CV. Haji Masagung, 1994.

al-Qardhawi, Yusuf. Ijtihad dalam Syariat Islam. Yogyakarta: IAIN Sunan Kalijaga, 1996. 